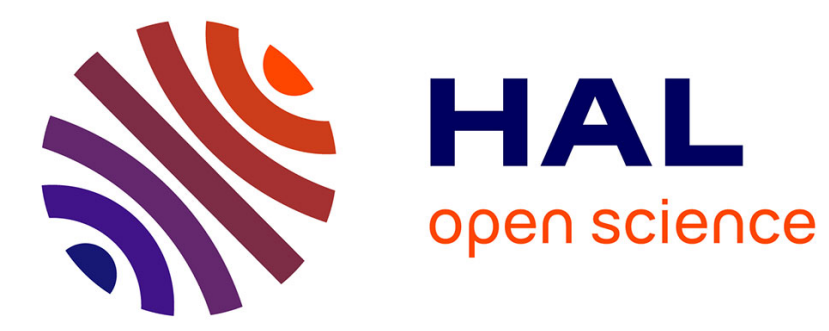

\title{
Estrogen receptor beta exerts growth-inhibitory effects on human mammary epithelial cells
}

Oliver Treeck, Claus Lattrich, Anette Springwald, Olaf Ortmann

\section{To cite this version:}

Oliver Treeck, Claus Lattrich, Anette Springwald, Olaf Ortmann. Estrogen receptor beta exerts growth-inhibitory effects on human mammary epithelial cells. Breast Cancer Research and Treatment, 2009, 120 (3), pp.557-565. 10.1007/s10549-009-0413-2 . hal-00535365

\section{HAL Id: hal-00535365 \\ https://hal.science/hal-00535365}

Submitted on 11 Nov 2010

HAL is a multi-disciplinary open access archive for the deposit and dissemination of scientific research documents, whether they are published or not. The documents may come from teaching and research institutions in France or abroad, or from public or private research centers.
L'archive ouverte pluridisciplinaire HAL, est destinée au dépôt et à la diffusion de documents scientifiques de niveau recherche, publiés ou non, émanant des établissements d'enseignement et de recherche français ou étrangers, des laboratoires publics ou privés. 


\title{
Estrogen receptor beta exerts growth-inhibitory effects on human mammary epithelial cells
}

\author{
Oliver Treeck • Claus Lattrich • Anette Springwald • \\ Olaf Ortmann
}

Received: 19 February 2009/Accepted: 23 April 2009/Published online: 12 May 2009

(C) Springer Science+Business Media, LLC. 2009

\begin{abstract}
Estrogen receptor $\beta(\mathrm{ER} \beta)$ is widely expressed in mammary epithelium. $\mathrm{ER} \beta$ expression is reported to decline during carcinogenesis of the breast and other tissues. In this study, we examined the consequences of a loss of $\operatorname{ER} \beta$ expression in mammary epithelial cells. We knocked down ER $\beta$ transcript levels in human mammary epithelial MCF-10A cells and in MCF-7 breast cancer cells by means of stable transfection with a specific shRNA plasmid. ER $\beta$ knockdown resulted in a significant growth increase of both cell types in a ligand-independent manner. This effect was accompanied by elevated cyclin A2 expression in MCF-10A cells and by decreased expression of growth-inhibitory p21/ $\mathrm{WAF}$ and epithelial cell marker cytokeratine 8 in both cell lines. Transfection of ER $\beta$ shRNA did not alter the absent proliferative estrogen response of MCF-10A cells, but conferred sensitivity to selective estrogen receptor modulator tamoxifen to this cell line. In contrast, $\mathrm{ER} \beta$ knockdown diminished estrogen responsiveness of MCF-7 breast cancer cells and also weakened the effect of tamoxifen on this cell line. These ligand-dependent effects only observed in MCF7 cells exhibiting a high $\mathrm{ER} \alpha / \beta$ ratio were accompanied by smaller estrogenic repression of p21/WAF expression, an impaired tamoxifen-triggered induction of this gene and by relative downregulation of $\mathrm{ER} \alpha$ and cyclin $\mathrm{A} 2$ transcript levels. Our data suggest that $\operatorname{ER} \beta$ exerts antiproliferative effects both on MCF-10A and MCF-7 cells in a ligand- and
\end{abstract}

O. Treeck · C. Lattrich · A. Springwald · O. Ortmann Department of Obstetrics and Gynecology, University of Regensburg, 93053 Regensburg, Germany

O. Treeck $(\bowtie)$

Lehrstuhl für Frauenheilkunde und Geburtshilfe der Universität Regensburg, Caritas Krankenhaus St. Josef, Landshuter Str. 65, 93053 Regensburg, Germany

e-mail: otreeck@ caritasstjosef.de
$\mathrm{ER} \alpha$-independent manner by regulation of $\mathrm{p} 21 / \mathrm{WAF}$ or cyclin A2 gene expression. Knockdown of ER $\beta$ in both cell types was sufficient to significantly decrease transcript levels of epithelial cell marker cytokeratin 8 . The results of this study support the hypothesis that $\mathrm{ER} \beta$ acts as a tumor suppressor in mammary epithelium.

Keywords Mammary epithelial cell - Breast cancer . Estrogen receptor beta $\cdot$ Proliferation

\section{Introduction}

Estrogens control growth and development of both normal and neoplastic mammary tissues, and mediate most of their action via ligand-dependent transcription factors called estrogen receptors (ER). Despite the fact that ER status is already an important biomarker in breast cancer [1] situation is now appreciated to be far more complex. Identification of a second ER, called ER $\beta$ [2] has led to a reevaluation of estrogen action in target tissues such as breast tumors. $\mathrm{ER} \beta$ is expressed in both normal and neoplastic human breast tissue [3,4] but its role in either is only beginning to be understood. In animal studies, while ER $\alpha$ has been shown to be essential for normal mammary gland development, $\mathrm{ER} \beta$ effects are more subtle, with roles in terminal differentiation [5] and modulation of $E R \alpha$ activity being described [6-8]. In contrast to ER $\alpha$, published data suggest that $\mathrm{ER} \beta$ expression declines during breast tumorigenesis [3, 9]. Nevertheless, ER $\beta$ expression in breast tumors varies widely $[4,10]$ and attempts to correlate $\operatorname{ER} \beta$ with various biomarkers have resulted in varied, often contradictory conclusions [11]. This might also be due to differential detection of variant non-ligand binding $\mathrm{ER} \beta$ proteins which have been detected in breast tissues 
$[12,13]$ and which code for proteins exerting functions distinct from that of the full-length $\operatorname{ER} \beta 1$ protein $[8,14]$. While the role of $\operatorname{ER} \beta$ in breast cancer is unclear, one important currently emerging hypothesis is that increased expression of $\operatorname{ER} \beta$ is associated with increased likelihood of response to endocrine therapy. Several studies report that increased levels of $\operatorname{ER} \beta$ were associated with a better disease outcome and consistent with the breast tumor being tamoxifen sensitive [15-19].

The observed downregulation of $\operatorname{ER} \beta$ in breast tumors compared with normal breast tissue suggested a role for $\operatorname{ER} \beta$ as a tumor suppressor [20]. This concept is supported by the results of various studies modifying $\operatorname{ER} \beta$ expression in human breast cancer cell lines. Overexpression of ER $\beta 1$ in different cancer cell lines resulted in a decrease of proliferation and motility, and an increased ability to enter apoptosis [21, 22].

This is the first study analyzing the effects of a shRNAmediated knockdown of $\operatorname{ER} \beta$ on a human mammary epithelial cell line. We compared the shRNA effects on gene expression and proliferation of immortalized mammary epithelial MCF-10A cells and MCF-7 breast cancer cells.

\section{Materials and methods}

\section{Materials}

Phenol red-free DMEM culture medium was obtained from Invitrogen (Karlsruhe, Germany), FCS was purchased from PAA (Pasching, Austria). 17- $\beta$ estradiol, 4-OH tamoxifen, epidermal growth factor (EGF), and serum replacement 2 (SR2) were obtained from Sigma (Deisenhofen, Germany), MCF-7 breast cancer cells and MCF-10A non-tumorigenic immortalized human mammary epithelial cells were obtained from American Type Culture Collection (Manassas, USA). M-MLV-P reverse transcriptase, Cell Titer Blue kit, and ImProm-II ${ }^{\mathrm{TM}}$ Reverse Transcriptase were purchased from Promega (Mannheim, Germany). RNeasy Mini Kit, RNase Free DNase Set, and Quantitect SYBR Green PCR Kit were obtained from Qiagen (Hilden, Germany). PCR primers were synthesized from Metabion (PlaneggMartinsried, Germany). Transfectin reagent was obtained from BioRad (Hercules, USA). Platinum Pfx Polymerase and OptiMEM medium were purchased from Invitrogen (Karlsruhe, Germany). SureSilencing shRNA plasmid for human ESR2 gene was purchased from SABiosciences, Frederick, USA.

Cell culture and transfections

MCF-10A cells were maintained in DMEM-F12 containing $10 \%$ FCS and 1 nM EGF. MCF-7 breast cancer cells were maintained in phenol red-free DMEM/F12 medium supplemented with $10 \% \mathrm{FCS}, 1 \mathrm{mM}$ sodiumpyruvate, and $10 \mathrm{ng} / \mathrm{ml}$ insulin. Cells were cultured with $5 \% \mathrm{CO}_{2}$ at $37^{\circ} \mathrm{C}$ in a humidified incubator. For transfection, $4 \times 10^{5}$ cells per well of a 6-well dish were seeded in DMEM/F12 containing $10 \%$ FCS. The next day, 2-ml fresh culture medium was added to the cells and transfection solution was prepared by mixing $5 \mu \mathrm{l}$ Transfectin reagent (BioRad) and $1 \mu \mathrm{g}$ of the shRNA plasmid mix or control plasmid DNA in OptiMEM reduced serum medium (Invitrogen) and added to the cultured cells. For transfection with $\operatorname{ER} \beta$ shRNA, a mixture of four plasmids (SureSilencing, SABiosciences, Frederick, USA) was used containing the $\mathrm{ER} \beta$-specific shRNA insert sequences $5^{\prime}$-cgccagttatcacatct gtat-3' (ESR2 exon 1), 5'-tcccagcaatgtcactaactt-3' (ESR2 exon 1), $5^{\prime}$-aggccatgatcctgctcaatt- $3^{\prime}$ (ESR2 exon 6 ), and $5^{\prime}$ gatcctgctcaattccagtat-3' (ESR2 exon 6/7). As a negative control, the same plasmid with the unspecific insert $5^{\prime}$ ggaatctcattcgatgcatac- $3^{\prime}$ was used. For generation of stable clones, G418 selection (300 $\mu \mathrm{g} / \mathrm{ml})$ was started $48 \mathrm{~h}$ after transfection and lasted for about 6 weeks before the first clones were isolated.

\section{Reverse transcription and real time PCR}

For gene expression analysis, cells cultured in DMEM/F12 supplemented with $1 \times \mathrm{SR} 2$ were treated with $1 \mathrm{nM}$ E2 alone or in combination with $100 \mathrm{nM} 4-\mathrm{OH}$ tamoxifen for 48 h. Total RNA was isolated by means of the RNeasy kit (Qiagen) according to the manufacturer's instructions. From $1 \mu \mathrm{g}$ total RNA, cDNA was synthesized using $100 \mathrm{U}$ M-MLV-P reverse transcriptase (Promega), 2, $5 \mathrm{mM}$ dNTP mixture, and $50 \mathrm{pM}$ random primers (Invitrogen). For real time PCR analyses (sequences of intron-spanning primers in Table. 1), $2 \mu \mathrm{l}$ of 1:5 diluted cDNA were amplified using the Quantitect SYBR Green PCR Kit (Qiagen) and the LightCyler PCR device (Roche Diagnostics, Mannheim, Germany). The PCR program was $95^{\circ} \mathrm{C}$ for $15 \mathrm{~min}$, followed by $35 \mathrm{PCR}$ cycles $\left(95^{\circ} \mathrm{C}\right.$ for $10 \mathrm{sec}, 56^{\circ} \mathrm{C}$ for $30 \mathrm{sec}$, and $72^{\circ} \mathrm{C}$ for $30 \mathrm{sec}$ ) and a final extension for 5 min at $72^{\circ} \mathrm{C}$, followed by a standard melting curve analysis. In all RT-PCR experiments, a 190 bp $\beta$-actin fragment was amplified as reference gene using intronspanning primers actin-2573 and actin-2876. After performing dilution experiments with sample cDNA over a 100 -fold range confirming the PCR efficiencies of all primer pairs to be approximately equal [23], data were analyzed using the comparative $\Delta \Delta \mathrm{C}_{\mathrm{T}}$ method [24] calculating the difference between the threshold cycle $\left(\mathrm{C}_{\mathrm{T}}\right)$ values of the target and reference gene of each sample and then comparing the resulting $\Delta \mathrm{C}_{\mathrm{T}}$ values between different samples. 
Table 1 Sequences of PCR primers used for real time RT-PCR

\begin{tabular}{lll}
\hline Gene & Primer $1\left(5^{\prime}-3^{\prime}\right)$ & Primer $2\left(5^{\prime}-3^{\prime}\right)$ \\
\hline ER $\beta 1$ & GGCATGCGAGTAACAAGGGC & GGGAGCCCTCTTTGCTTTT \\
ER $\beta 2$ & GTTTGGGTGATTGCCAAGAG & TCTGCCCTCGCATG \\
ER $\beta 5$ & GTTTGGGTGATTGCCAAGAG & GCACATAATCCCATCCCAAG \\
ER $\alpha$ & CACATGAGTAACAAAGGCATGG & ATGAAGTAGAGCCCGCAGTG \\
PR & AACTTGCATGATCTTGTCAAACA & CACCATCCCTGCCAATATCT \\
P21/WAF & GCATGACAGATTTCTACCACTCC & AAGATGTAGAGCGGGCCTTT \\
CYC D 1 & CTGGAGGTCTGCGAGGAA & GGGGATGGTCTCCTTCATCT \\
CYC A2 & CTGCTGCTATGCTGTTAGCC & TGTTGGAGCAGCTAAGTCAAAA \\
C-Fos & AGAATCCGAAGGGAAAGGAA & CTTCTCCTTCAGCAGGTTGG \\
CK8 & GCAATGATGCTGTCCATGTC & AGGCAGCTATATGAAGAGGAGA \\
\hline
\end{tabular}

Cell viability assay

MCF-10A and MCF-7 wildtype (WT) cells or ER $\beta$-shRNA clones were seeded in 96-well plates in triplicates (1000 cells/well), cultured in DMEM containing $1 \times$ serum replacement 2 (SR2), and were treated with different concentrations of $17-\beta$ estradiol (E2) or with $1 \mathrm{nM}$ E2 in combination with different concentrations of 4-OH tamoxifen. After $0,72,96$, and $120 \mathrm{~h}$, relative numbers of viable cells were measured in comparison to the untreated control and the solvent control using the fluorimetrical, resazurin-based Cell Titer Blue assay (Promega) according to the manufacturer's instructions at $560_{E x} / 590_{E m} \mathrm{~nm}$ in a Victor3 multilabel counter (PerkinElmer, Germany). Cell growth was expressed as percentage of day 0 or percentage of the untreated medium control. Statistical analysis of the data was performed by one-way ANOVA using Prism 2.0 Software (Graph pad, San Diego, USA), with statistical significance accepted at $P<0.05$.

\section{Results}

Knockdown of $\mathrm{ER} \beta$ in MCF-10A mammary

epithelial cells

To study the function of $\operatorname{ER} \beta$ in human mammary epithelial cells, we performed a siRNA-mediated knockdown of this receptor in MCF-10A cells and additionally in MCF-7 breast cancer cells. For this purpose, we transfected both MCF-7 and MCF-10A cells with a shRNA plasmid for human ESR2 (SureSilencing, SABiosciences, Frederick, USA) or with a negative control plasmid. After 6 weeks of G418 selection, we picked three clones of each cell line and determined the transcript levels of $\operatorname{ER} \beta 1, \beta 2$, and $\beta 5$ by real time RT-PCR analysis. In the negative control clones, ER $\beta$ mRNA levels were similar in MCF-7 and MCF-10A cells, with the highest level detected of $\mathrm{ER} \beta 5$ splice variant.
Stable expression of ESR2 shRNA led to reduction of $\mathrm{ER} \beta$ transcript levels by at least $80 \%$ in both cell lines (Fig. 1). This knockdown effect was verified by analysis of three $\operatorname{ER} \beta$ splice variants. However, we did not observe significant differences in the $\operatorname{ER} \beta$ expression levels between the three clones of each cell line. The generated cell lines were termed $\mathrm{MCF}-7 / \beta \mathrm{KD}$ or $\mathrm{MCF}-10 \mathrm{~A} / \beta \mathrm{KD}$, respectively. After
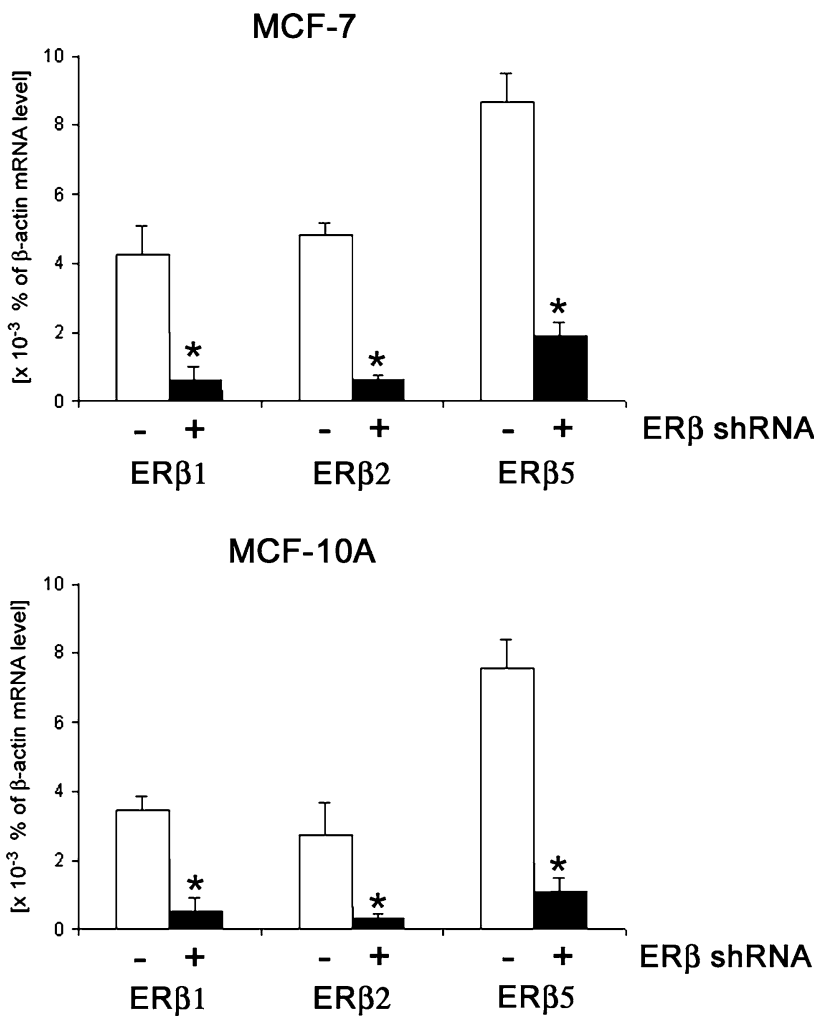

Fig. 1 Validation of $\operatorname{ER} \beta$ knockdown resulting from stable expression of $\operatorname{ER} \beta$ shRNA. Transcript levels of $\operatorname{ER} \beta 1, \beta 2$, and $\beta 5$ were relatively quantified by means of real time RT-PCR and are expressed in percent of $\beta$-actin mRNA levels. The white bars illustrate the respective transcript levels in negative control cells, the black bars show the effect of stable expression of $\operatorname{ER} \beta$ shRNA $(n=4)$. $* P<0.01$ vs. control 


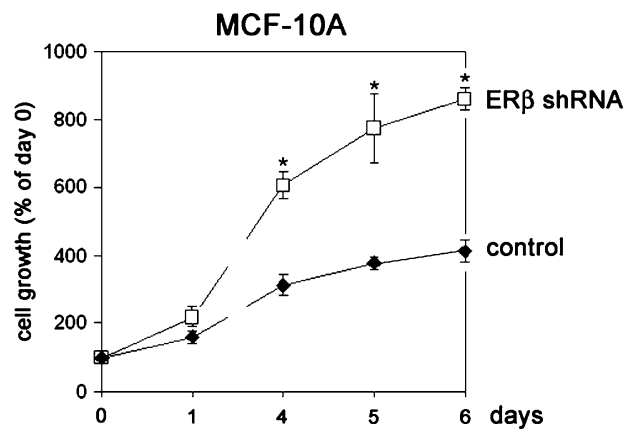

Fig. 2 Proliferation of MCF-10 and MCF-7 cells transfected with an $\operatorname{ER} \beta$ shRNA plasmid. Cells were cultured for 6 days in defined, serum- and estrogen-free medium. Cell growth was determined on

real time RT-PCR analysis, we also intended to verify the knockdown of $\operatorname{ER} \beta$ on protein level by means of western blot analysis. We were able to detect ER $\alpha$ protein in MCF-7 cells (data not shown), but we got no specific $\mathrm{ER} \beta$ band at all neither in MCF-7 nor in MCF-10A cells, a result that could be explained by the about $10^{3}$-fold weaker expression of $\operatorname{ER} \beta$ than $\operatorname{ER} \alpha$ on the mRNA level.

\section{Knockdown of ER $\beta$ increases proliferation}

of MCF-10A mammary epithelial cells

Next we compared the growth of MCF-7/ $\beta \mathrm{KD}$ or MCF$10 \mathrm{~A} / \beta \mathrm{KD}$ cells with the negative control clone of each cell line. In our proliferation assays using defined, E2- and phenolred-free culture medium, decreased $\operatorname{ER} \beta$ transcript

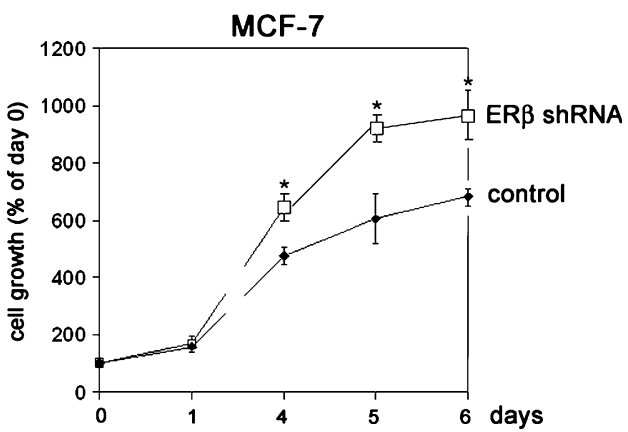

day $0,1,4,5$, and 6 by means of a resazurin-based assay as described in the materials and methods section. Data are expressed in percent of day $0 .(n=4) .{ }^{*} P<0.01$ vs. control

levels clearly led to an increased growth of both cell lines. This ligand-independent effect was even more pronounced in the relatively slowly proliferating mammary epithelial cell line MCF-10A, where loss of ER $\beta$-accelerated cell growth more than twofold (Fig. 2). A similar effect on cell growth was observed in proliferation assays using FBSsupplemented cell culture conditions (data not shown).

To examine the relevance of $\operatorname{ER} \beta$ for the cellular estrogen response of both cell lines, we then treated these clones cultured in defined medium with different concentrations of $17-\beta$ estradiol for up to 5 days. Whereas MCF-7 cells responded with the expected, dose-dependent acceleration of cell growth, E2-effect on proliferation of MCF-7/ $\beta \mathrm{KD}$ cells was significantly smaller (Fig. $3 \mathrm{a}$ ). In contrast, this steroid hormone did not significantly affect growth of
Fig. 3 Proliferative response to E2 and 4-OH tamoxifen (TAM). Cells were cultured for 5 days in defined medium containing the indicated concentrations of estradiol alone or in combination with TAM. Cell growth was determined by means of a resazurin-based assay as described in the materials and methods section. Data are expressed in percent of growth of EtOH-treated cells (upper panel) or in percent of growth of $\mathrm{E} 2+\mathrm{EtOH}$-treated cells (lower panel; $n=4$ ). $* P<0.01$ vs. control
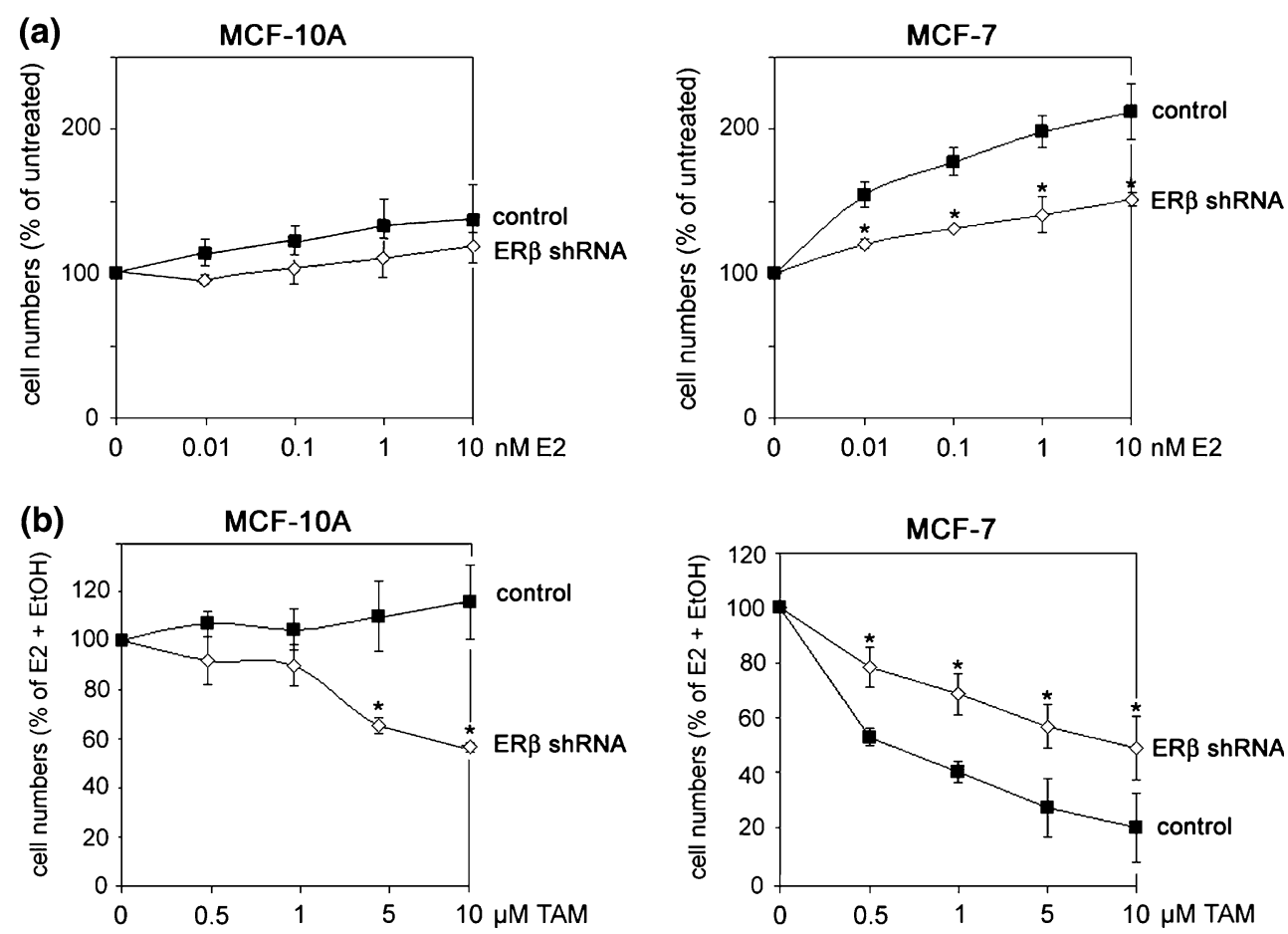
MCF-10A cells, and ER $\beta$-knockdown did not significantly alter estrogen responsivity of this cell line.

Given that $\operatorname{ER} \beta$ is discussed to affect the efficacy of an endocrine therapy with the selective estrogen receptor modulator (SERM) tamoxifen, we used our cell models to examine this question. For this purpose, cells cultured in defined medium containing $1 \mathrm{nM} 17-\beta$ estradiol were treated with different concentrations of the metabolite 4$\mathrm{OH}$ tamoxifen for 5 days. Treatment with tamoxifen dosedependently led to a strong decrease of viable MCF-7 cell numbers. In contrast, MCF-7 cells with reduced ER $\beta$ mRNA levels exhibited a significantly decreased sensitivity to this SERM (Fig. 3b).

Growth of estrogen-unresponsive MCF-10A cells was not affected by this drug. Interestingly, knockdown of ER $\beta$ mRNA in this mammary epithelial cell line significantly increased its sensitivity to 5 and $10 \mu \mathrm{M}$ tamoxifen. Treatment with these concentrations of tamoxifen for 5 days decreased viable MCF-10A/ $\beta$ KD cell numbers by $35-45 \%$ (Fig. 3b).

Ligand-independent gene expression changes in human mammary epithelial MCF-10A/ $\beta$ KD cells

Next we studied gene expression changes which could underly the increased growth rate of MCF-10A cells with $\mathrm{ER} \beta$-knockdown cultured in E2-free medium. For this purpose, we have chosen a candidate gene approach and analyzed expression of the steroid hormone receptors ER $\alpha$ and progesterone receptor (PR), the proliferation-associated genes c-fos, p21 WAF, Cyclin D1, and Cyclin A2, and the epithelial cell marker cytokeratin 8 (CK8) by means of real time RT-PCR. Cells were cultured in defined, serumand E2-free medium, thus the following results describe gene expression changes which are ligand-independent and are triggered only be decrease of $\operatorname{ER} \beta$ mRNA.

In contrast to MCF-7 cells, ER $\alpha$ mRNA was not detectable in MCF-10A cells, irrespective their $\mathrm{ER} \beta$ status. Expression of PR was significantly higher in MCF-7 than in MCF-10A cells, but was not changed by ER $\beta$-knockdown in both cell lines. Transcript levels of c-fos proto-oncogene were about 2.5-fold higher in MCF-7 than in MCF-10A cells and were also not affected by altered ER $\beta$ levels.

Stable expression of ER $\beta$-shRNA significantly reduced mRNA levels of cyclin-dependent kinase inhibitor p21 WAF- 1 by about $80 \%$ in MCF-10A/ $\beta$ KD cells and by about $60 \%$ in MCF-7/ $\beta$ KD cells (Fig. 4). In MCF- $10 \mathrm{~A} / \beta \mathrm{KD}$ cells, p21 transcript levels were in a similar range as in wildtype MCF-7 breast cancer cells. Expression of cell cycle regulators cyclin D1 and A2 was similarly pronounced in both cell lines tested. Whereas in MCF-7 breast cancer cells, it was not affected by ER $\beta$ status, MCF-10A/ $\beta$ KD cells exhibited more than twofold elevated cyclin A2 transcript levels.
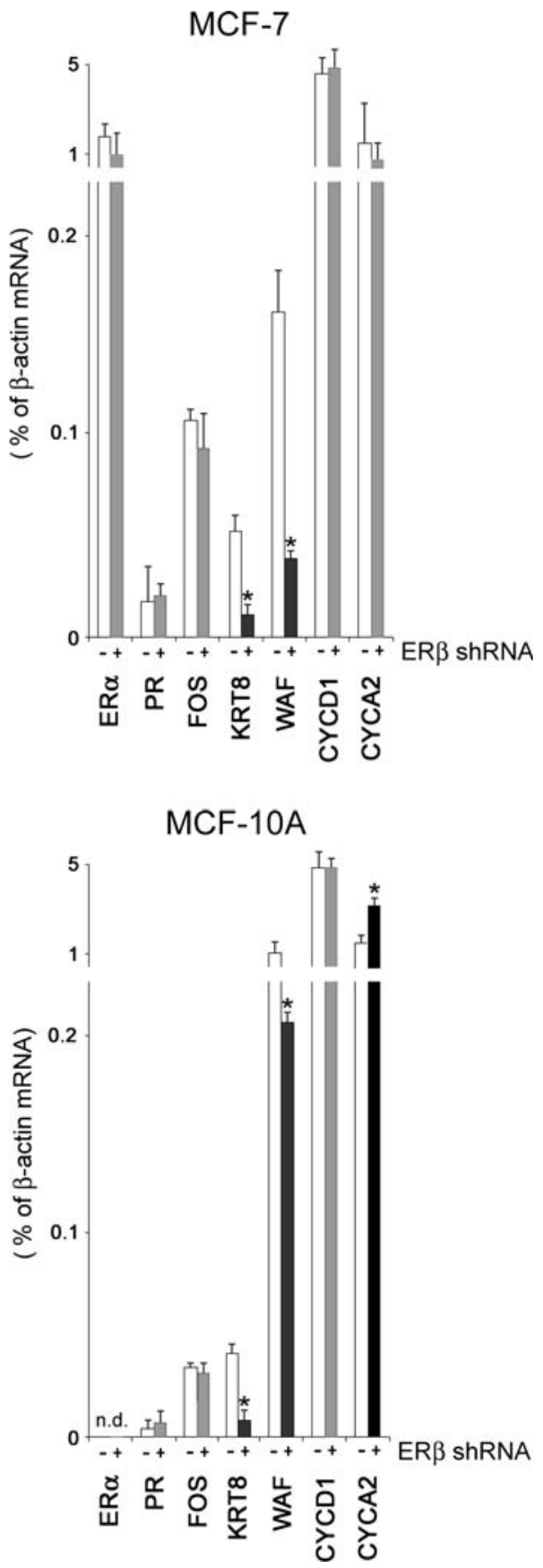

Fig. 4 Gene expression changes triggered by knockdown of ER $\beta$ (ESR2) gene in a ligand-independent manner. The week before isolation of total RNA, cells were cultured in defined, phenolred- and E2-free medium. Expression of the indicated genes was relatively quantified on the mRNA level by means of real time RT-PCR. White bars: expression level in negative control cells. Gray and black bars: mRNA level in the indicated cell lines expressing ER $\beta$ shRNA. Data are expressed in percent of $\beta$-actin transcript level. $* P<0.01$ vs. negative control cells

Knockdown of ER $\beta$ mRNA decreased expression of epithelial cell marker cytokeratine 8 . In both cell lines tested, the $\beta \mathrm{KD}$ clones exhibited cytokeratin $8 \mathrm{mRNA}$ 
levels which were about $75 \%$ smaller than in the respective wildtype cells (Fig. 4).

Ligand-dependent gene expression changes in human mammary epithelial MCF-10A/ $\beta$ KD cells

Last we examined gene expression changes which could underly the altered proliferative response of MCF-10A/ $\beta \mathrm{KD}$ and MCF-7/ $\beta \mathrm{KD}$ cells to $17-\beta$ estradiol and to $4-\mathrm{OH}$ tamoxifen (TAM). For this purpose, the respective cell lines were treated with E2 $(1 \mathrm{nM})$ alone or in combination with TAM for $48 \mathrm{~h}$, and the isolated RNA again was analyzed by means of real time RT-PCR.

PR mRNA levels were more than sixfold elevated in MCF-7 cells treated with E2, an effect which was totally blocked by co-treatment with TAM and which was not observed in the mammary epithelial cell line MCF-10A. However, this E2-effect on PR expression did not seem to be dependent on $\mathrm{ER} \beta$ status. ER $\alpha$ mRNA was not detected in MCF-10A cells, but in MCF-7/ $\beta \mathrm{KD}$ cells, treatment with $\mathrm{E} 2$ led to a significant down-regulation of ER $\alpha$ mRNA (Fig. 5). This E2-triggered decrease of ER $\alpha$ transcript levels was roughly the same size as the tamoxifen effect on expression of this steroid hormone receptor.

Transcript levels of cell cycle inhibitor p21 were significantly decreased after E2 treatment in MCF-7 wildtype cells, but not in MCF-7 cells expressing ER $\beta$ shRNA. Treatment with TAM nearly doubled p21 mRNA levels in MCF-7 cells, but only slightly increased p21 expression in MCF-7/ $\beta$ KD cells. Whereas the TAM-triggered upregulation of p21 mRNA was also present in MCF-10A cells irrespective the $\mathrm{ER} \beta$ status, E2 did not significantly downregulate $\mathrm{p} 21$ in this cell line.

Treatment with E2 doubled cyclin A2 transcript levels in MCF-7 cells, but this effect was significantly less pronounced in MCF-7 cells expressing ER $\beta$ shRNA (Fig. 5). In contrast, E2 slightly diminished cyclin A2 expression in MCF-10A wildtype cells, but increased expression of this gene in MCF- $10 \mathrm{~A} / \beta \mathrm{KD}$ cells. In the mammary epithelial cell line, treatment with tamoxifen lowered cyclin A2 mRNA levels by about $50 \%$, irrespective of ER $\beta$ status. Whereas expression of cell cycle regulator cyclin D1 was not affected by E2 or TAM in MCF-7 cells or in MCF-10A wildtype cells, its transcript levels were doubled by treatment with TAM in MCF-10A cells lacking normal ER $\beta$ expression (Fig. 5).

\section{Discussion}

Estrogen receptor $\beta$ is known to exert anti-proliferative effects on human cancer cell lines derived from hormone-dependent tissues, such as breast or prostate [21, 25]. In human cancer cells, this effect of $\operatorname{ER} \beta$ has previously been described to be mediated by direct or indirect repression of cyclin expression and activation of growth-inhibitory genes like p21 (WAF1) [22]. Various studies reported ER $\beta$ to be the dominant estrogen receptor in mammary epithelial cells [3, 9, 20]. Given that $\operatorname{ER} \beta$ is known to antagonize $\operatorname{ER} \alpha$ in specific settings, it was suggested that in this tissue, $\operatorname{ER} \beta$ might be the key inhibitor of ER $\alpha$-mediated proliferation. A decline of ER $\beta$ expression, resulting in an increase of $\mathrm{ER} \alpha / \beta$ ratio, which is observed in benign hyperplasia and more frequently observed in breast cancer, would lead to an undamped E2-triggered, ER $\alpha$-mediated cellular proliferation.

Whereas the function of ER $\beta$ in breast cancer cells has been examined previously, this is the first study analyzing the effect of an ER $\beta$-knockdown in a mammary epithelial cell line. MCF-10A cells are normal mammary epithelial cells which had immortalized spontaneously and which are non-tumorigenic [26]. The expression analyses in this study on mRNA level demonstrated that $\operatorname{ER} \beta$ is the dominant receptor in this mammary epithelial cell line, whereas $\mathrm{ER} \alpha$ expression is so low that it was not detectable by RTPCR. In contrast, in MCF-7 breast cancer cells, ER $\alpha$ is the dominant receptor. However, this difference did not result from lower ER $\beta$-expression in MCF-7 cells, but from significantly stronger expression of $\mathrm{ER} \alpha$ in this breast cancer cell line.

Stable transfection of both cell lines with a plasmid coding for ER $\beta$ shRNA resulted in a significant knockdown on ER $\beta$ expression, which was confirmed on mRNA level. We also intended to test this effect on protein level by means of western blot analysis, but were only able to detect $\mathrm{ER} \alpha$ in MCF-7 cells, and got an ER $\beta$-band only in the peptide control lane (data not shown). However, this is not surprising considering the about $10^{3}$-fold lower transcript levels of $\mathrm{ER} \beta$ when compared with ER $\alpha$ mRNA in MCF-7 cells. Given that all efforts to optimize our western blot protocol (using different methods for nuclear extraction, using different $\mathrm{ER} \beta$ antibodies) did not succeed, we had to restrict this study to the mRNA level.

Knockdown of ER $\beta$ mRNA resulted in a significant growth increase of MCF-10A cells, even when cultured under serum- and E2-free conditions. This cell line normally grows rather slow, but expression of ER $\beta$-shRNA raised its growth rate until the level of MCF-7 cells and even beyond. The observation of a similar effect of $\operatorname{ER} \beta$ shRNA on MCF-7 breast cancer cells supports previous studies reporting a decrease of cell growth in breast cancer cells overexpressing ER $\beta$ [21, 22]. On molecular level, the enhanced growth of MCF-10A $/ \beta \mathrm{KD}$ cells was accompanied by fivefold downregulation of growth-inhibitory p21 (WAF1) gene and a significant increase of cyclin A2 
PR

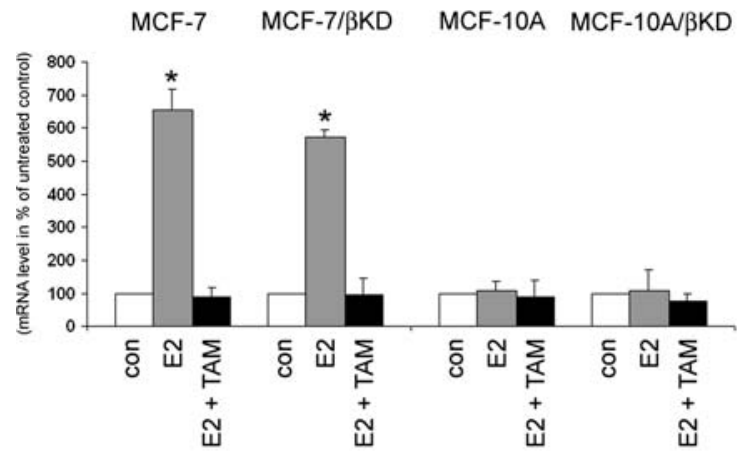

$\mathrm{ER} \alpha$

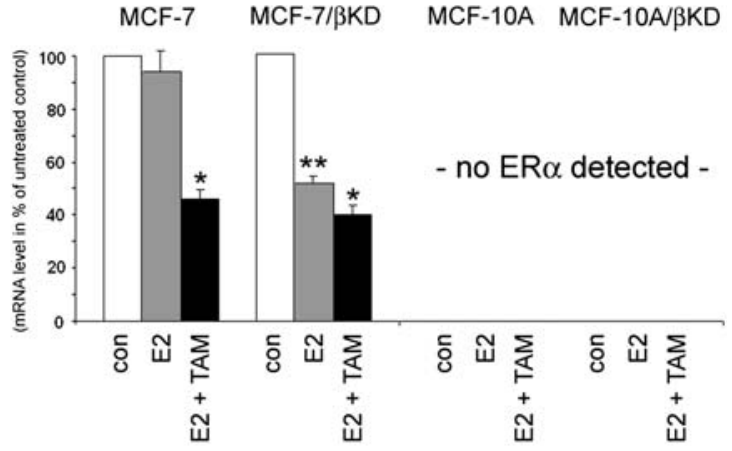

p21/WAF

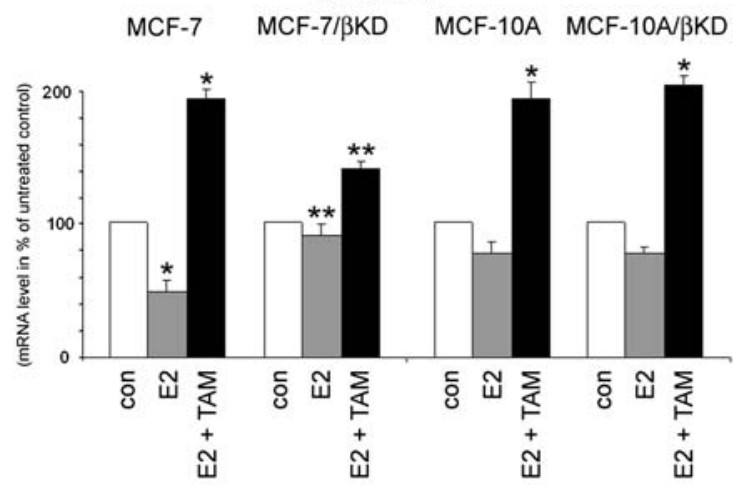

Cyclin A2

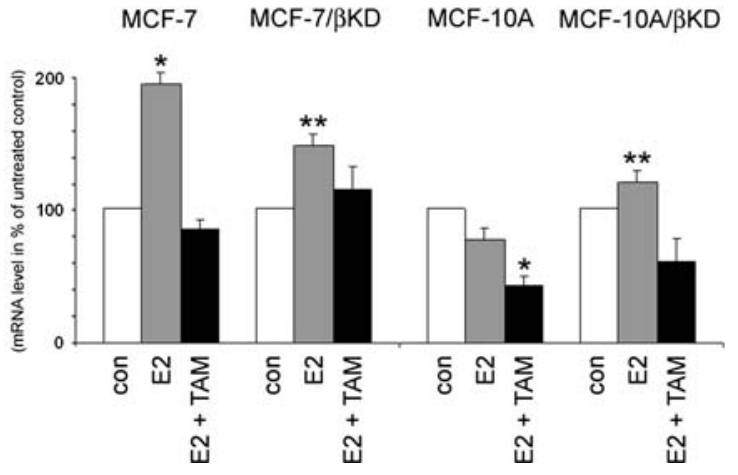

Fig. 5 Gene expression changes triggered by treatment with E2 or TAM in the indicated cell lines. Before isolation of total RNA, cells were treated with E2 $(1 \mathrm{nM})$ or TAM $(5 \mu \mathrm{M})$ for $48 \mathrm{~h}$. Expression of the indicated genes was relatively quantified on the mRNA level by

transcripts, clearly suggesting that these genes are important mediators of $\operatorname{ER} \beta$ action in mammary epithelial cells. Whereas in a previous study, ER $\beta$ overexpression in MCF7 cells resulted in a decrease of cyclin D1 and cyclin A2 expression and an increase of p21 (WAF1) mRNA levels, we did not observe any association between $\operatorname{ER} \beta$-status and cyclin expression in this cell line [22]. However, downregulation of $\operatorname{ER} \beta$ mRNA levels in our study resulted in a significant decrease of $\mathrm{p} 21$ (WAF1) expression in MCF-7
Cyclin D1

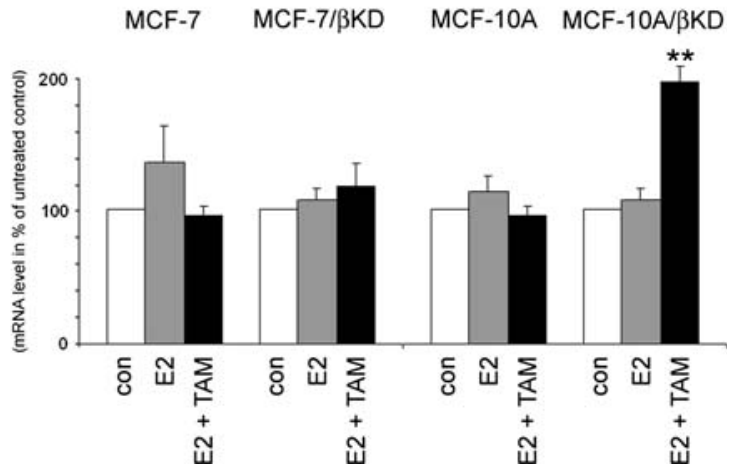

means of real time RT-PCR. Data are expressed in percent of expression in untreated cells. $* P<0.01$ vs. untreated cells, $* P<0.05$ vs. negative control cells

cells, supporting the observations of the study mentioned earlier.

Both in cytokeratin 8 (CK8)-positive MCF-10A and MCF-7 cells, expression of ER $\beta$-shRNA led to a significant decrease of CK8 transcript levels. Cytokeratin 8 gene codes for an intermediate filament protein that polymerizes with CK18 to form a component of the cytoskeleton of epithelial cells. CK8 expression as a differentiation marker of epithelial cells is frequently lost during epithelial-mesenchymal 
transition in breast cancer development [27]. In breast cancer patients, a loss of CK8 expression is associated with a higher risk for recurrence and death [28]. Given that a high $\mathrm{ER} \beta / \alpha$ ratio is considered as a marker of normal mammary epithelium, our data suggest that loss of $\mathrm{ER} \beta$ expression may lead to decrease of CK8 expression, thereby promoting the epithelial-mesenchymal transition. Downregulation of CK8 expression resulted from ER $\beta$ knockdown both in CK8-positive MCF-7 breast cancer cells and in MCF-10A mammary epithelial cells, thereby supporting the hypothesis of $\operatorname{ER} \beta$ being a tumor suppressor.

In contrast to MCF-7 breast cancer cells, growth of MCF-10A cells was not affected by E2, an observation explainable by the negative ER $\alpha$-status of the mammary epithelial cell line. Whereas knockdown of $\operatorname{ER} \beta$ mRNA did not alter the absent estrogen response of MCF-10A cells, it significantly impaired estrogen-triggered proliferation (but not PR expression) of MCF-7 cells. However, in the latter cell line expressing ER $\beta$ shRNA, growth rate already was strongly increased in absence of E2, which might be the reason for the observation of a larger relative E2-effect in wildtype MCF-7 cells. In our gene expression analyses, we identified a possible molecular mechanism underlying the decreased proliferative estrogen response of MCF-7/ $\beta \mathrm{KD}$ cells. After treatment with E2, MCF-7 cells expressing $\mathrm{ER} \beta$ shRNA exhibited significantly lowered ER $\alpha$ transcript levels, suggesting that ER $\beta$ might counteract E2-triggered downregulation of $\mathrm{ER} \alpha$, thereby sustaining $\mathrm{ER} \alpha$-mediated estrogen response. E2 significantly reduced p21/WAF1 mRNA levels and increased cylin A2 levels in wildtype MCF-7 cells, but only to a significantly smaller extent in MCF-7 cells with ER $\beta$ knockdown. This observation can be explained considering the transcript levels of growth inhibitor p21/WAF1 being already decreased in MCF-7/ $\beta \mathrm{KD}$ cells cultured without $\mathrm{E} 2$, whereas mRNA levels of cyclin A2 were already increased in the absence of E2, so that the relative effect of $\mathrm{E} 2$ on expression of both genes had to be smaller in MCF-7/ $\beta \mathrm{KD}$ cells.

Expression of ER $\beta$ shRNA conferred tamoxifen sensitivity to MCF-10A cells, but weakened the effect of this SERM on MCF-7 breast cancer cells. Given that in MCF10A cells, tamoxifen increased p21/WAF transcript levels and decreased cyclin A2 expression irrespective of $\mathrm{ER} \beta$ status, we do not have an explanation for this effect. However, the decreased activity of tamoxifen in MCF-7 cells expressing ER $\beta$ shRNA supports recent publications reporting high $\mathrm{ER} \beta$ expression to be associated with good response to an endocrine therapy $[29,30]$. Our data also suggest a molecular mechanism which could underly the weakened tamoxifen response, in $\mathrm{MCF}-7 / \beta \mathrm{KD}$ cells, tamoxifen-triggered induction of $\mathrm{p} 21 / \mathrm{WAF}$ expression was significantly weaker. Whether p21/WAF might be an applicable predictive factor for tamoxifen response has to be evaluated in further studies.

This is the first study examing the function of $\operatorname{ER} \beta$ in a mammary epithelial cell line by means of RNA interference. Our data suggest that ER $\beta$ might delimit growth both of mammary epithelial cells and breast cancer cells in a ligand- and $E R \alpha$-independent manner. On molecular level, this effect could be mediated by ER $\beta$-dependent upregulation of growth-inhibitory p21/WAF1 and in MCF-10A cells additionally by downregulation of cyclin A2 mRNA levels. The strong decline of epithelial cell marker cytokeratine 8 transcript levels both in mammary epithelial and breast cancer cells expressing ER $\beta$-shRNA further supports the hypothesis of $\operatorname{ER} \beta$ being a tumor suppressor. Our data from MCF-7 breast cancer cells exhibiting a high ER $\alpha / \beta$ ratio suggest that in such cells a second, ligand- and ER $\alpha$ dependent mode of action of $\operatorname{ER} \beta$ might exists. In the presence of $\mathrm{ER} \alpha$, estrogen-bound $\mathrm{ER} \beta$ might support the proliferative estrogen effect mediated through the $\alpha$ receptor by direct or indirect elevation of $\mathrm{ER} \alpha$ and cyclin A2 expression and by repression of p21/WAF1.

Acknowledgments We thank Helena Houlihan and Gerhard Piendl for their excellent technical assistance.

\section{References}

1. Ali S, Coombes RC (2002) Endocrine-responsive breast cancer and strategies for combating resistance. Nat Rev Cancer 2(2):101-112. doi:10.1038/nrc721

2. Kuiper GG, Enmark E, Pelto-Huikko M, Nilsson S, Gustafsson JA (1996) Cloning of a novel receptor expressed in rat prostate and ovary. Proc Natl Acad Sci USA 93(12):5925-5930. doi: 10.1073/pnas.93.12.5925

3. Leygue E, Dotzlaw H, Watson P, Murphy L (1998) Altered estrogen receptor alpha and beta mRNA expression during human breast tumorigenesis. Cancer Res 58:3197-3201

4. Jarvinen T, Pelto-Huikko M, Holli K, Isola J (2000) Estrogen receptor beta is coexpressed with ERalpha and PR and associated with nodal status grade and proliferation rate in breast cancer. Am J Pathol 156:29-35

5. Forster C, Makela S, Warri A, Kietz S, Becker D, Hultenby K, Warner M, Gustafsson J (2002) Involvement of estrogen receptor $\mathrm{b}$ in terminal differentiation of mammary gland epithelium. Proc Natl Acad Sci USA 99:15578-15583. doi:10.1073/pnas.192 561299

6. Hall J, McDonnell D (1999) The estrogen receptor betaisoform (ERbeta) of the human estrogen receptor modulates ERalpha transcriptional activity and is a key regulator of the cellular response to estrogens and antiestrogens. Endocrinology 140: 5566-5578. doi:10.1210/en.140.12.5566

7. Weihua Z, Saji S, Makinen S, Cheng G, Jensen E, Warner M, Gustaffson JA (2000) Estrogen receptor (ER) b a modulator of ERa in the uterus. Proc Natl Acad Sci USA 97:5936-5941. doi: 10.1073/pnas.97.11.5936

8. Peng B, Lu B, Leygue E, Murphy L (2003) Putative functional characteristics of human estrogen receptor-beta isoforms. J Mol Endocrinol 30:13-29. doi:10.1677/jme.0.0300013 
9. Roger P, Sahla M, Makela S, Gustafsson JA, Baldet P, Rochefort H (2001) Decreased expression of estrogen receptor beta protein in proliferative preinvasive mammary tumors. Cancer Res 61:2537-2541

10. Dotzlaw H, Leygue E, Watson P, Murphy L (1999) Estrogen receptor-b messenger RNA expression in human breast tumor biopsies: relationship to steroid receptor status and regulation by progestins. Cancer Res 59:529-532

11. Speirs V (2002) Oestrogen receptor beta in breast cancer: good bad or still too early to tell? J Pathol 197:143-147. doi: 10.1002/path.1072

12. Fuqua S, Schiff R, Parra I, Friedrichs W, Su J, McKee D, SlentzKesler K, Moore L, Willson T, Moore J (1999) Expression of wild-type estrogen receptor beta and variant isoforms in human breast cancer. Cancer Res 59:5425-5428

13. Saji S, Omoto Y, Shimizu C, Warner M, Hayashi Y, Horiguchi S, Watanabe T, Hayashi S, Gustafsson J (2002) Expression of estrogen receptor (ER) (beta)cx protein in ER(alpha)-positive breast cancer: specific correlation with progesterone receptor. Cancer Res 62:4849-4853

14. Saji S, Omoto Y, Shimizu C, Horiguchi S, Watanabe T, Funata N, Hayash S, Gustafsson J, Toi M (2002) A Clinical impact of assay of estrogen receptor beta $\mathrm{cx}$ in breast cancer. Breast Cancer 9:303-307. doi:10.1007/BF02967608

15. Mann S, Laucirica R, Carlson N, Younes PS, Ali N, Younes A, Li Y, Younes M (2001) Estrogen receptor beta expression in invasive breast cancer. Hum Pathol 32(1):113-118. doi:10.1053/hupa. 2001.21506

16. Murphy L, Cherlet T, Lewis A, Banu Y, Watson P (2003) New insights into estogen receptor function in human breast cancer. Ann Med 35:614-631. doi:10.1080/07853890310014579

17. Esslimani-Sahla M, Simony-Lafontaine J, Kramar A, Lavaill R, Mollevi C, Warner M, Gustafsson J-A, Rochefort H (2004) Estrogen receptor beta (ERbeta) level but not its ERbeta-cx variant helps to predict tamoxifen resistance in breast cancer. Clin Cancer Res 10:5769-5776. doi:10.1158/1078-0432.CCR-040389

18. Fleming F, Hill A, McDermott E, O'Higgins N, Young L (2004) Differential recruitment of coregulator proteins steroid receptor coactivator-1 and silencing mediator for retinoid and thyroid receptors to the estrogen receptorestrogen response element by beta-estradiol and 4-hydroxytamoxifen in human breast cancer. $\mathbf{J}$ Clin Endocrinol Metab 89:375-383. doi:10.1210/jc.2003-031048

19. Hopp TA, Weiss HL, Parra IS, Cui Y, Osborne CK, Fuqua SA (2004) Low levels of estrogen receptor beta protein predict resistance to tamoxifen therapy in breast cancer. Clin Cancer Res 10(22):7490-7499. doi:10.1158/1078-0432.CCR-04-1114

20. Skliris G, Munot K, Bell S, Carder P, Lane S, Horgan K, Lansdown M, Parkes A, Hanby A, Markham A, Speirs V (2003)
Reduced expression of oestrogen receptor beta in invasive breast cancer and its re-expression using DNA methyltransferase inhibitors in a cell line model. J Pathol 201:213-220. doi: 10.1002/path.1436

21. Treeck O, Juhasz-Boess I, Lattrich C, Horn F, Goerse R, Ortmann $\mathrm{O}$ (2008) Effects of exon-deleted estrogen receptor $\beta$ transcript variants on growth, apoptosis and gene expression of human breast cancer cell lines. Breast Cancer Res Treat 110(3):507-520. doi:10.1007/s10549-007-9749-7

22. Paruthiyil S, Parmar H, Kerekatte V, Cunha GR, Firestone GL, Leitman DC (2004) Estrogen receptor beta inhibits human breast cancer cell proliferation and tumor formation by causing a G2 cell cycle arrest. Cancer Res 64(1):423-428. doi:10.1158/ 0008-5472.CAN-03-2446

23. Ståhlberg A, Åman P, Ridell B, Mostad P, Kubista M (2003) A quantitative real-time PCR method for detection of B-lymphocyte monoclonality by comparison of kappa and lambda immunoglobulin light chain expression. Clin Chem 49(1):51-59. doi: 10.1373/49.1.51

24. Livak KJ, Schmittgen TD (2001) Analysis of relative gene expression data using real-time quantitative PCR and the 2($\Delta \Delta \mathrm{C}_{\mathrm{T}}$ ) method. Methods 25(4):402-408. doi:10.1006/meth.2001. 1262

25. Cheng J, Lee EJ, Madison LD, Lazennec G (2004) Expression of estrogen receptor beta in prostate carcinoma cells inhibits invasion and proliferation and triggers apoptosis. FEBS Lett 566(13):169-172. doi:10.1016/j.febslet.2004.04.025

26. Soule HD et al (1990) Isolation and characterization of a spontaneously immortalized human breast epithelial MCF- 10. Cancer Res 50:6075-6086

27. Fuchs IB, Lichtenegger W, Buehler H, Henrich W, Stein H, Kleine-Tebbe A, Schaller G (2002) The prognostic significance of epithelial-mesenchymal transition in breast cancer. Anticancer Res 22(6A):3415-3419

28. Bonin S, Brunetti D, Benedetti E, Dotti I, Gorji N, Stanta G (2008) Molecular characterisation of breast cancer patients at high and low recurrence risk. Virchows Arch 452(3):241-250. doi:10.1007/s00428-007-0570-9

29. Honma N, Horii R, Iwase T, Saji S, Younes M, Takubo K, Matsuura M, Ito Y, Akiyama F, Sakamoto G (2008) Clinical importance of estrogen receptor-beta evaluation in breast cancer patients treated with adjuvant tamoxifen therapy. J Clin Oncol 26(22):3727-3734. doi:10.1200/JCO.2007.14.2968

30. Hodges-Gallagher L, Valentine CD, El Bader S, Kushner PJ (2008) Estrogen receptor beta increases the efficacy of antiestrogens by effects on apoptosis and cell cycling in breast cancer cells. Breast Cancer Res Treat 109(2):241-250. doi:10.1007/ s10549-007-9640-6 